Acta Crystallographica Section E

Structure Reports

Online

ISSN 1600-5368

\section{Decaaquadioxidobis $\left[\mu_{3}-N\right.$-(phosphon- atomethyl)iminodiacetato]dizinc(II)- divanadium(IV) dihydrate}

\section{Luís Cunha-Silva, ${ }^{a}$ Fa-Nian Shi, ${ }^{a}$ Jacek Klinowski, ${ }^{b}$ Tito Trindade, ${ }^{a}$ João Rocha ${ }^{\mathrm{a}}$ and Filipe A. Almeida Paz ${ }^{\mathrm{a} *}$}

${ }^{a}$ Department of Chemistry, University of Aveiro, CICECO, 3810-193 Aveiro, Portugal, and ${ }^{\mathbf{b}}$ Department of Chemistry, University of Cambridge, Lensfield Road, Cambridge CB2 1EW, England

Correspondence e-mail: filipe.paz@ua.pt

Received 20 November 2007; accepted 22 November 2007

Key indicators: single-crystal X-ray study; $T=293 \mathrm{~K}$; mean $\sigma(\mathrm{C}-\mathrm{C})=0.003 \AA$; $\mathrm{H}$ atom completeness $89 \% ; R$ factor $=0.027 ; w R$ factor $=0.077$; data-to-parameter ratio $=17.0$.

The title compound, $\left[\mathrm{Zn}_{2} \mathrm{~V}_{2}\left(\mathrm{C}_{5} \mathrm{H}_{6} \mathrm{NO}_{7} \mathrm{P}\right)_{2} \mathrm{O}_{2}\left(\mathrm{H}_{2} \mathrm{O}\right)_{10}\right] \cdot 2 \mathrm{H}_{2} \mathrm{O}$, contains a $\left.\left[\mathrm{V}_{2} \mathrm{O}_{2} \text { (pmida }\right)_{2}\right]^{4-}$ dimeric anionic unit [where $\mathrm{H}_{4}$ pmida is $\mathrm{N}$-(phosphonomethyl)iminodiacetic acid] lying on a centre of symmetry which is exo-coordinated via the two deprotonated phosphonate groups to two $\mathrm{Zn}^{2+}$ cations, with the coordination environment of $\mathrm{Zn}$ completed by five water molecules. The crystal packing is mediated by an extensive network of strong and highly directional $\mathrm{O}-\mathrm{H} \cdots \mathrm{O}$ hydrogen bonds involving the water molecules (coordinated and uncoordinated) and the functional groups of pmida $^{4-}$, leading to a three-dimensional supramolecular network.

\section{Related literature}

For related literature, see: Cunha-Silva, Mafra et al. (2007); Cunha-Silva, Shi et al. (2007); Shi et al. (2007); Mafra et al. (2006); Shi, Paz, Girginova, Amaral et al. (2006); Shi, Paz, Girginova, Rocha et al. (2006); Shi, Almeida Paz, Trindade \& Rocha (2006); Paz, Rocha, Klinowski et al. (2005); Almeida Paz, Shi, Mafra et al. (2005); Almeida Paz, Shi, Trindade et al. (2005); Shi et al. (2005); Paz et al. (2004).

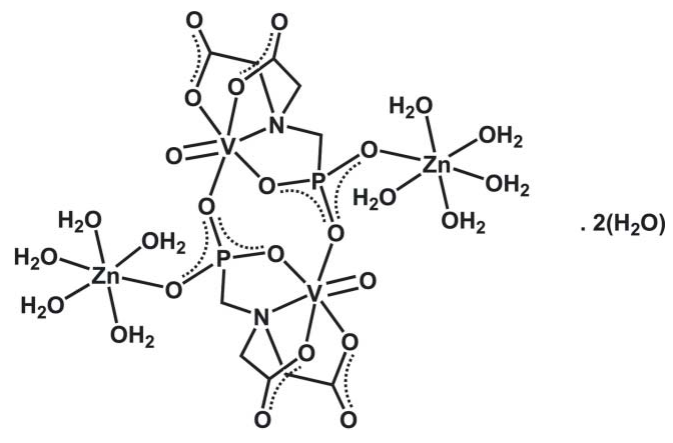

\section{Experimental}

Crystal data

$\left[\mathrm{Zn}_{2} \mathrm{~V}_{2}\left(\mathrm{C}_{5} \mathrm{H}_{6} \mathrm{NO}_{7} \mathrm{P}\right)_{2} \mathrm{O}_{2}\left(\mathrm{H}_{2} \mathrm{O}\right)_{10}\right] \cdot$. $2 \mathrm{H}_{2} \mathrm{O}$

$M_{r}=926.97$

Monoclinic, $P 2_{1} / c$

$a=10.0161(5) \AA$

$b=14.8811(7) \AA$

$c=10.8298(5) \AA$

$\beta=111.147(2)^{\circ}$

$V=1505.48(12) \AA^{3}$

$Z=2$

Mo $K \alpha$ radiation

$\mu=2.40 \mathrm{~mm}^{-1}$

$T=293(2) \mathrm{K}$

$0.22 \times 0.14 \times 0.10 \mathrm{~mm}$

Data collection

Bruker Kappa APEXII diffractometer

Absorption correction: multi-scan (SADABS; Sheldrick, 1998)

$T_{\min }=0.621, T_{\max }=0.796$

95509 measured reflections 4040 independent reflections 3765 reflections with $I>2 \sigma(I)$ $R_{\text {int }}=0.028$

Refinement

$R\left[F^{2}>2 \sigma\left(F^{2}\right)\right]=0.027$

$w R\left(F^{2}\right)=0.077$

$S=1.04$

4040 reflections

238 parameters

15 restraints

$\mathrm{H}$ atoms treated by a mixture of independent and constrained refinement

$\Delta \rho_{\max }=1.06{\mathrm{e} \AA^{-3}}^{-3}$

$\Delta \rho_{\min }=-0.87{\mathrm{e} \AA^{-3}}^{-3}$

Table 1

Selected bond lengths ( $\mathrm{A})$.

\begin{tabular}{llll}
\hline $\mathrm{Zn} 1-\mathrm{O} 7$ & $2.0133(14)$ & $\mathrm{V} 1-\mathrm{O} 8$ & $1.6086(16)$ \\
$\mathrm{Zn} 1-\mathrm{O} 3 W$ & $2.0609(16)$ & $\mathrm{V} 1-\mathrm{O} 6^{\mathrm{i}}$ & $1.9890(14)$ \\
$\mathrm{Zn} 1-\mathrm{O} 1 W$ & $2.0860(17)$ & $\mathrm{V} 1-\mathrm{O} 5$ & $1.9932(14)$ \\
$\mathrm{Zn} 1-\mathrm{O} 4 W$ & $2.0974(16)$ & $\mathrm{V} 1-\mathrm{O} 2$ & $2.0312(15)$ \\
$\mathrm{Zn} 1-\mathrm{O} 5 W$ & $2.1440(18)$ & $\mathrm{V} 1-\mathrm{O} 4$ & $2.0321(14)$ \\
$\mathrm{Zn} 1-\mathrm{O} 2 W$ & $2.1660(15)$ & $\mathrm{V} 1-\mathrm{N} 1$ & $2.3590(16)$ \\
\hline
\end{tabular}

Symmetry code: (i) $-x+2,-y+1,-z+1$.

Table 2

Hydrogen-bond geometry $\left(\AA{ }^{\circ}\right)$.

\begin{tabular}{|c|c|c|c|c|}
\hline$D-\mathrm{H} \cdots A$ & $D-\mathrm{H}$ & $\mathrm{H} \cdots A$ & $D \cdots A$ & $D-\mathrm{H} \cdots A$ \\
\hline $\mathrm{O} 1 W-\mathrm{H} 1 W \cdots \mathrm{O} 1^{\mathrm{ii}}$ & $0.90(2)$ & $1.88(2)$ & $2.770(2)$ & $169(3)$ \\
\hline $\mathrm{O} 1 W-\mathrm{H} 2 W \cdots \mathrm{O} 2 W^{\mathrm{ii}}$ & $0.90(2)$ & $1.95(2)$ & $2.828(2)$ & $164(3)$ \\
\hline $\mathrm{O} 2 W-\mathrm{H} 3 W \cdots \mathrm{O} 3^{\mathrm{iii}}$ & $0.88(2)$ & $1.85(2)$ & $2.725(2)$ & $172(3)$ \\
\hline $\mathrm{O} 2 W-\mathrm{H} 4 W \cdots \mathrm{O} 5^{\mathrm{ii}}$ & $0.87(2)$ & $1.93(2)$ & $2.795(2)$ & $173(3)$ \\
\hline $\mathrm{O} 3 W-\mathrm{H} 6 W \cdots \mathrm{O} 2^{\mathrm{ii}}$ & $0.88(2)$ & $1.87(2)$ & $2.733(2)$ & $171(3)$ \\
\hline $\mathrm{O} 3 W-\mathrm{H} 5 W \cdots \mathrm{O} 4^{\mathrm{iv}}$ & $0.89(2)$ & $1.86(2)$ & $2.726(2)$ & $164(4)$ \\
\hline $\mathrm{O} 4 W-\mathrm{H} 7 W \cdots \mathrm{O} 3^{\text {iv }}$ & $0.86(2)$ & $1.98(2)$ & $2.837(2)$ & $174(3)$ \\
\hline $\mathrm{O} 4 W-\mathrm{H} 8 W \cdots \mathrm{O} 1^{\mathrm{v}}$ & $0.88(2)$ & $1.94(2)$ & $2.799(2)$ & $167(3)$ \\
\hline $\mathrm{O} 5 W-\mathrm{H} 9 W \cdots \mathrm{O} 6$ & $0.90(2)$ & $1.98(3)$ & $2.805(2)$ & $150(4)$ \\
\hline $\mathrm{O} 5 W-\mathrm{H} 10 W \cdots \mathrm{O} 6 W$ & $0.86(2)$ & $1.84(3)$ & $2.656(6)$ & $159(4)$ \\
\hline
\end{tabular}

Data collection: APEX2 (Bruker, 2006); cell refinement: APEX2; data reduction: $S A I N T$ (Bruker, 2005); program(s) used to solve structure: SHELXTL (Bruker 2001); program(s) used to refine structure: SHELXTL; molecular graphics: DIAMOND (Brandenburg, 2006); software used to prepare material for publication: SHELXTL.

The authors are grateful to the Fundação para a Ciência e a Tecnologia (FCT, Portugal) for their general financial support (grant No. POCI-PPCDT/QUI/58377/2004 supported by FEDER), for specific funding toward the purchase of the 


\section{metal-organic compounds}

single-crystal diffractometer, and also for Postdoctoral Research Grants SFRH/BPD/14410/2003 (to LCS) and SFRH/ BPD/9309/2002 (to FNS).

Supplementary data and figures for this paper are available from the IUCr electronic archives (Reference: BG2149).

\section{References}

Almeida Paz, F. A., Shi, F.-N., Mafra, L., Makal, A., Wozniak, K., Trindade, T., Klinowski, J. \& Rocha, J. (2005). Acta Cryst. E61, m1628-m1632.

Almeida Paz, F. A., Shi, F.-N., Trindade, T., Klinowski, J. \& Rocha, J. (2005). Acta Cryst. E61, m2247-m2250.

Brandenburg, K. (2006). DIAMOND. Version 3.1e. Crystal Impact GbR, Bonn, Germany.

Bruker (2001). SHELXTL. Version 6.12. Bruker AXS Inc. Madison, Wisconsin, USA.

Bruker (2005). SAINT-Plus. Version 7.23a. Bruker AXS Inc. Madison, Wisconsin, USA.

Bruker (2006). APEX2. Version 2.1-RC13. Bruker AXS, Delft, The Netherlands.
Cunha-Silva, L., Mafra, L., Ananias, D., Carlos, L. D., Rocha, J. \& Paz, F. A. A. (2007). Chem. Mater. 19, 3527-3538.

Cunha-Silva, L., Shi, F.-N., Klinowski, J., Trindade, T., Rocha, J. \& Almeida Paz, F. A. (2007). Acta Cryst. E63, m372-m375.

Mafra, L., Paz, F. A. A., Shi, F.-N., Rocha, J., Trindade, T., Fernandez, C., Makal, A., Wozniak, K. \& Klinowski, J. (2006). Chem. Eur. J. 12, 363-375.

Paz, F. A. A., Rocha, J., Klinowski, J., Trindade, T., Shi, F.-N. \& Mafra, L. (2005). Prog. Solid State Chem. 33, 113-125.

Paz, F. A. A., Shi, F.-N., Klinowski, J., Rocha, J. \& Trindade, T. (2004). Eur. J. Inorg. Chem. pp. 2759-2768.

Sheldrick, G. M. (1998). SADABS. Version 2.01. Bruker AXS Inc. Madison, Wisconsin, USA.

Shi, F.-N., Almeida Paz, F. A., Trindade, T. \& Rocha, J. (2006). Acta Cryst. E62, m335-m338.

Shi, F.-N., Cunha-Silva, L., Sá Ferreira, R. A., Mafra, L., Trindade, T., Carlos, L. D., Paz, F. A. A. \& Rocha, J. (2007). J. Am. Chem. Soc. doi: 10.1021/ ja074119k

Shi, F.-N., Paz, F. A. A., Girginova, P. I., Amaral, V. S., Rocha, J., Klinowski, J. \& Trindade, T. (2006). Inorg. Chim. Acta, 359, 1147-1158.

Shi, F.-N., Paz, F. A. A., Girginova, P. I., Mafra, L., Amaral, V. S., Rocha, J., Makal, A., Wozniak, K., Klinowski, J. \& Trindade, T. (2005). J. Mol. Struct. 754, 51-60.

Shi, F.-N., Paz, F. A. A., Girginova, P. I., Rocha, J., Amaral, V. S., Klinowski, J. \& Trindade, T. (2006). J. Mol. Struct. 789, 200-208. 


\section{supporting information}

Acta Cryst. (2008). E64, m39-m40 [https://doi.org/10.1107/S1600536807062253]

\section{Decaaquadioxidobis $\left[\mu_{3}-\mathrm{N}\right.$-(phosphonatomethyl)iminodiacetato]- dizinc(II) divanadium(IV) dihydrate}

\section{Luís Cunha-Silva, Fa-Nian Shi, Jacek Klinowski, Tito Trindade, João Rocha and Filipe A. Almeida}

Paz

\section{S1. Comment}

Research on highly crystalline organic-inorganic hybrids, in particular those belonging to the family of coordination polymers, has received a considerable attention over the last two decades. Such occurs as a direct consequence of the fascinating structural architectures achieved by assembling organic ligands and metal centres which, in many cases, can be allied with interesting potential applications (e.g. gas storage, separation, catalysis, guest exchange, magnetic or optical sensors). Following our ongoing research toward the hydrothermal synthesis and structural characterization of this type of materials, we recently focused our attention on the use of multifunctional ligands such as $N$-(phosphonomethyl)iminodiacetic acid (H4pmida) (Cunha-Silva, Shi et al., 2007; Mafra et al., 2006; Shi, Paz, Girginova, Amaral et al., 2006; Shi, Paz, Girginova, Rocha et al., 2006; Shi, Almeida Paz, Trindade \& Rocha, 2006; Paz, Rocha, Klinowski et al., 2005; Almeida Paz, Shi, Mafra et al., 2005; Almeida Paz, Shi, Trindade et al., 2005; Shi et al., 2005; Paz et al., 2004), 1-hydroxyethylidene-1,1-diphosphonic acid ( $\mathrm{H}_{5}$ hedp) (Shi et al., 2007), and nitrilotris(methylenephosphonic acid) $\left(\mathrm{H}_{6} \mathrm{nmp}\right)$ (Cunha-Silva, Mafra et al., 2007), we report here the structural details of the title compound, $\left.\left[\mathrm{Zn}_{2} \mathrm{~V}_{2} \mathrm{O}_{2} \text { (pmida) }\right)_{2}\left(\mathrm{H}_{2} \mathrm{O}\right)_{10}\right] \cdot 2 \mathrm{H}_{2} \mathrm{O}$ (I) [where pmida ${ }^{4}$ stands for $\mathrm{C}_{5} \mathrm{H}_{6} \mathrm{NO}_{7} \mathrm{P}^{4-}$.

The structure of (I) contains two crystallographically unique metal centres, Zn1 and V1, both exhibiting octahedral coordination geometries, $\left\{\mathrm{ZnO}_{6}\right\}$ and $\left\{\mathrm{VO}_{5} \mathrm{~N}\right\}$ (see table of selected geometric parameters and Fig. 1). $\mathrm{Zn} 1$ is coordinated by five $\mathrm{O}$ atoms of five crystalographically independent water molecules and one $\mathrm{O}$ atom from the $\mu_{3}$-bridging phosphonate group of pmida ${ }^{4-}$ (Fig. 1), with the overall coordination geometry resembling a slightly distorted octahedron [ $\mathrm{Zn}-\mathrm{O}$ bond lengths found in the 2.0133 (14)-2.1660 (15) $\AA$ range; cis and trans $\mathrm{O}-\mathrm{Zn}-\mathrm{O}$ octahedral angles ranging from 87.09 (8) to $91.64(6)^{\circ}$ and from 177.27 (7) to $178.11(7)^{\circ}$, respectively; see table of selected geometric parameters].

The two symmetry-related $\mathrm{Zn}^{2+}$ cations of the neutral tetranuclear $\left[\mathrm{Zn}_{2} \mathrm{~V}_{2} \mathrm{O}_{2}(\text { pmida })_{2}\left(\mathrm{H}_{2} \mathrm{O}\right)_{10}\right]$ molecule depicted in Fig. 1 are connected through the phosphonate groups belonging to the central centrosymmetric dimeric anionic $\left[\mathrm{V}_{2} \mathrm{O}_{2}(\mathrm{pmida})_{2}\right]^{4-}$ unit, with intermetallic $\mathrm{Zn} 1 \cdots \mathrm{Zn} 1^{\mathrm{i}}, \mathrm{Zn} 1 \cdots \mathrm{V} 1$ and $\mathrm{V} 1 \cdots \mathrm{V} 1^{\mathrm{i}}$ distances of 10.0170 (5), 3.2447 (5) and 3.8773 (5) $\AA$, respectively [symmetry code: (i) $2-x, 1-y, 1-z$ ]. It is of considerable importance to emphasize that the geometrical aspects of this dimeric anionic unit are typical and in good agreement with those described in detail in our previous publications (Shi et al., 2007; Shi, Paz, Girginova, Amaral et al., 2006; Shi, Paz, Girginova, Rocha et al., 2006; Shi, Almeida Paz, Trindade \& Rocha, 2006; Paz, Rocha, Klinowski et al., 2005; Almeida Paz, Shi, Mafra et al., 2005; Almeida Paz, Shi, Trindade et al., 2005; Shi et al., 2005; Paz et al., 2004). V1 is connected to one oxo group and to two pmida $^{4-}$ ligands, with the geometry of the first coordination sphere resembling a highly distorted octahedron, which is composed by one short $\mathrm{V}-\mathrm{O}$ bond [1.6088 (16) $\AA$ ], four intermediate $\mathrm{V}-\mathrm{O}$ bonds [1.9890 (12)-2.0321 (14) $\AA$ ] and a long $\mathrm{V}-\mathrm{N}$ bond [2.3590 (16) $\AA$ ]; the cis and trans internal octahedral angles range from 86.67 (6) to $103.84(8)^{\circ}$, and 
from 154.45 (6) to $169.79(8)^{\circ}$, respectively. Noteworthy is the structural evidence of the notable trans effect of the oxo group over the long $\mathrm{V}-\mathrm{N}$ distance (see Table of selected geometric parameters).

Individual $\left[\mathrm{Zn}_{2} \mathrm{~V}_{2} \mathrm{O}_{2}(\text { pmida })_{2}\left(\mathrm{H}_{2} \mathrm{O}\right)_{10}\right]$ molecular units close pack with the water molecules of crystallization in a typical brick-wall-like fashion in the $b c$ plane of the unit cell (Fig. 2), mediated by an extensive network of strong and highly directional $\mathrm{O}-\mathrm{H} \cdots \mathrm{O}$ hydrogen bonding interactions (see Table summarizing the geometrical aspects of the hydrogen bonds).

\section{S2. Experimental}

Starting materials were purchased from commercial sources and were used as received without further purification: $N$-(phosphonomethyl)iminodiacetic acid hydrate $\left(\mathrm{H}_{4}\right.$ pmida, $\mathrm{C}_{5} \mathrm{H}_{10} \mathrm{NO}_{7} \mathrm{P}, 97 \%$, Fluka), potassium metavanadate $\left(\mathrm{KVO}_{3}\right.$, $98 \%$, Aldrich), zinc oxide ( $\mathrm{ZnO}, 98 \%$, Panreac), imidazole $\left(\mathrm{C}_{3} \mathrm{H}_{4} \mathrm{~N}_{2}, 99.0 \%\right.$, Panreac) and adipic acid ( $\mathrm{HOOC}\left(\mathrm{CH}_{2}\right)_{4} \mathrm{COOH}, 99 \%$, Aldrich).

A mixture containing $0.26 \mathrm{~g}$ of $\mathrm{KVO}_{3}, 0.15 \mathrm{~g}$ of $\mathrm{ZnO}, 0.42 \mathrm{~g}$ of $\mathrm{H}_{4} \mathrm{pmida}, 0.13 \mathrm{~g}$ of imidazole and $0.27 \mathrm{~g}$ of adipic acid in $c a 9 \mathrm{~g}$ of distilled water, was stirred thoroughly at ambient temperature for 30 minutes, yielding a suspension with a molar composition of $c a$ 1:1:1:1:1:270, respectively, which was transferred to a PTFE-lined stainless steel reaction vessel (total volume $c a 40 \mathrm{ml}$ ). The reaction vessel was placed inside a preheated oven at $473 \mathrm{~K}$ for one day, after which the temperature was decreased to $373 \mathrm{~K}$ allowing the reaction to proceed for another four days. After reacting, under autogeneous pressure and static conditions, the vessel was removed from the oven and left to cool to ambient temperature before opening. Small amounts of green and/or blue mixed powders of unknown phases were readily separated from the mother liquor by vacuum filtering. Large single crystals of the title compound were isolated by slow evaporation (in open air) of the mother liquor over the period of one week. It is of considerable importance to emphasize that similar reactions where imidazole and adipic acid were not included in the starting reactive mixture failed in the isolation of the title material.

\section{S3. Refinement}

$\mathrm{H}$ atoms bound to carbon were placed at idealized positions and allowed to ride on their parent atoms with $U_{\text {iso }}$ fixed at $1.2 \times U_{\text {eq }}(\mathrm{C}) . \mathrm{H}$ atoms associated with the five coordinated water molecules were markedly visible in difference Fourier maps and were included in the structural model for subsequent least-squares refinement cycles with the $\mathrm{O}-\mathrm{H}$ and $\mathrm{H}^{\cdots} \mathrm{H}$ distances restrained to 0.90 (3) and 1.47 (3) Å, respectively, in order to ensure a chemically reasonable geometry for these chemical moieties. These $\mathrm{H}$ atoms were allowed to ride on their parent atoms with $U_{\text {iso }}$ fixed at $1.5 \times U_{\text {eq }}(\mathrm{O})$.

The crystallographically unique O6W water molecule of crystallization was directly located from difference Fourier maps and refined assuming a full site occupancy and a thermal anisotropic displacement behaviour. The $\mathrm{H}$ atoms associated with this chemical moiety could not be unequivocally located from difference Fourier maps. Additionally, attempts to place the two $\mathrm{H}$ atoms in calculated positions did not produce a chemically reasonable structural model, in particular concerning the geometry of the resulting hydrogen bonding interactions. Therefore, these $\mathrm{H}$ atoms were omitted from the final structural model but were included in the empirical chemical formula. 


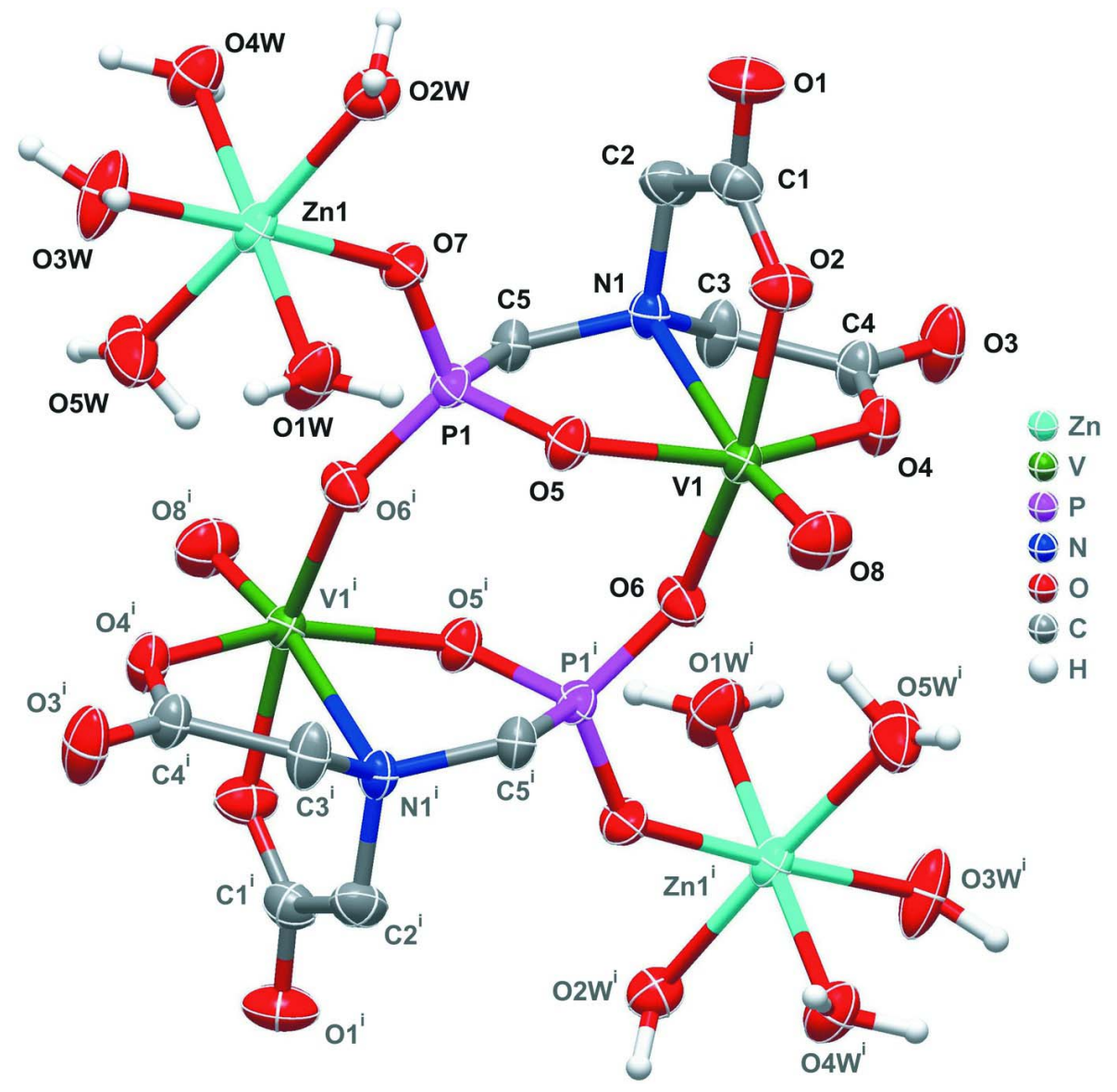

Figure 1

Schematic representation of the tetranuclear centrosymmetric $\left[\mathrm{Zn}_{2} \mathrm{~V}_{2} \mathrm{O}_{2}(\text { pmida })_{2}\left(\mathrm{H}_{2} \mathrm{O}\right)_{10}\right]$ molecular unit, showing the labelling scheme for all non-H atoms. Displacement ellipsoids are drawn at the $50 \%$ probability level and $\mathrm{H}$ atoms are represented as small spheres with arbitrary radii. The water molecule of crystallization O6W was omitted for clarity. Symmetry transformation used to generate equivalent atoms (in grey): $2-x, 1-y, 1-z$. 


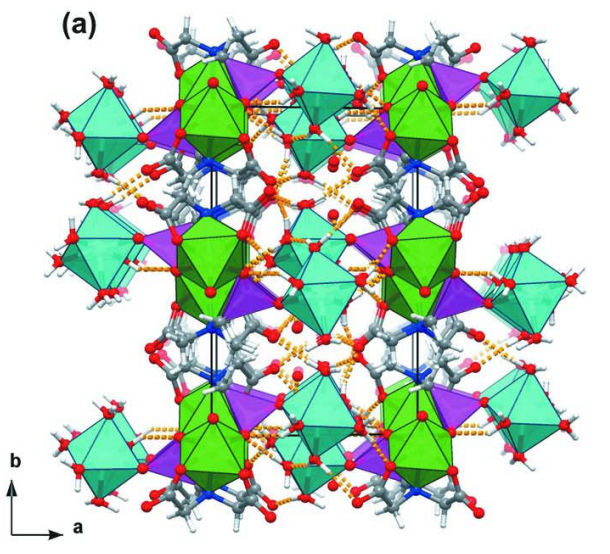

(b)
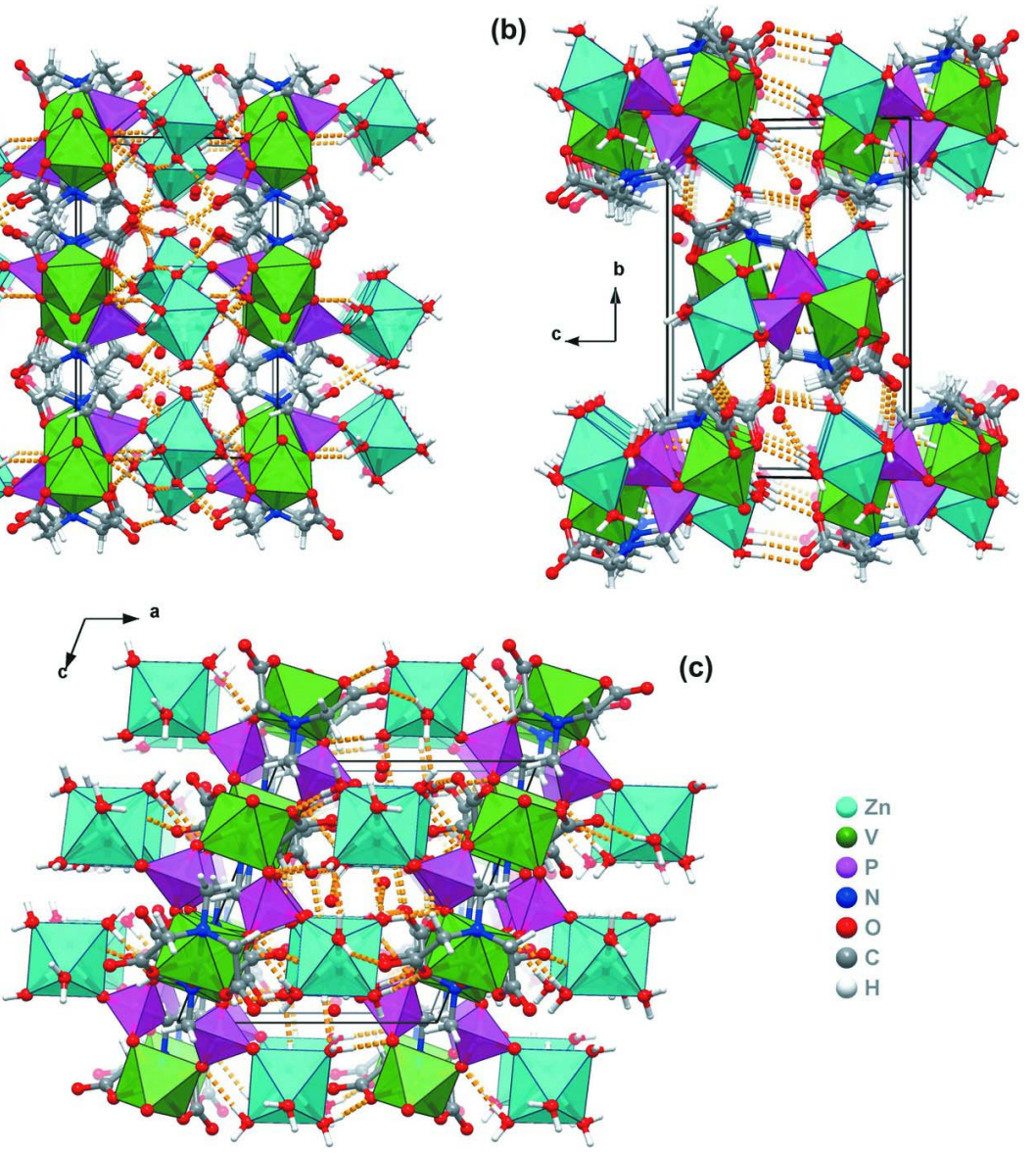

Figure 2

Crystal packing of the title compound viewed in perspective along the (a) [001], (b) [100] and (c) [010] directions of the unit cell. Hydrogen bonds are represented as orange dashed lines.

Decaaquadioxidobis $\left[\mu_{3}-\mathrm{N}-\right.$ (phosphonatomethyl)iminodiacetato]dizinc(II)divanadium(IV) dihydrate

\section{Crystal data}

$\left[\mathrm{Zn}_{2} \mathrm{~V}_{2}\left(\mathrm{C}_{5} \mathrm{H}_{6} \mathrm{NO}_{7} \mathrm{P}\right)_{2} \mathrm{O}_{2}\left(\mathrm{H}_{2} \mathrm{O}\right)_{10}\right] \cdot 2 \mathrm{H}_{2} \mathrm{O}$

$M_{r}=926.97$

Monoclinic, $P 2{ }_{1} / c$

Hall symbol: -P 2ybc

$a=10.0161$ (5) $\AA$

$b=14.8811$ (7) $\AA$

$c=10.8298(5) \AA$

$\beta=111.147(2)^{\circ}$

$V=1505.48(12) \AA^{3}$

$Z=2$

\section{Data collection}

\section{Bruker X8 APEXII Kappa CCD}

diffractometer

Radiation source: fine-focus sealed tube

Graphite monochromator

Thin-slice $\omega$ and $\varphi$ scans
$F(000)=940$

$D_{\mathrm{x}}=2.045 \mathrm{Mg} \mathrm{m}^{-3}$

Mo $K \alpha$ radiation, $\lambda=0.71073 \AA$

Cell parameters from 9009 reflections

$\theta=2.6-37.6^{\circ}$

$\mu=2.40 \mathrm{~mm}^{-1}$

$T=293 \mathrm{~K}$

Prism, blue

$0.22 \times 0.14 \times 0.10 \mathrm{~mm}$

Absorption correction: multi-scan

(SADABS; Sheldrick, 1998)

$T_{\min }=0.621, T_{\max }=0.796$

95509 measured reflections

4040 independent reflections

3765 reflections with $I>2 \sigma(I)$ 


$$
\begin{aligned}
& R_{\text {int }}=0.028 \\
& \theta_{\max }=29.1^{\circ}, \theta_{\min }=3.6^{\circ} \\
& h=-13 \rightarrow 13
\end{aligned}
$$

\section{Refinement}

Refinement on $F^{2}$

Least-squares matrix: full

$R\left[F^{2}>2 \sigma\left(F^{2}\right)\right]=0.027$

$w R\left(F^{2}\right)=0.077$

$S=1.04$

4040 reflections

238 parameters

15 restraints

Primary atom site location: structure-invariant direct methods $k=-20 \rightarrow 20$

$l=-14 \rightarrow 14$

Secondary atom site location: difference Fourier map

Hydrogen site location: inferred from neighbouring sites

$\mathrm{H}$ atoms treated by a mixture of independent and constrained refinement

$w=1 /\left[\sigma^{2}\left(F_{\mathrm{o}}^{2}\right)+(0.038 P)^{2}+2.056 P\right]$ where $P=\left(F_{\mathrm{o}}^{2}+2 F_{\mathrm{c}}^{2}\right) / 3$

$(\Delta / \sigma)_{\max }=0.002$

$\Delta \rho_{\max }=1.06 \mathrm{e} \AA^{-3}$

$\Delta \rho_{\min }=-0.87$ e $\AA^{-3}$

\section{Special details}

Experimental. See dedicated section in the main paper

Geometry. All e.s.d.'s (except the e.s.d. in the dihedral angle between two 1.s. planes) are estimated using the full covariance matrix. The cell e.s.d.'s are taken into account individually in the estimation of e.s.d.'s in distances, angles and torsion angles; correlations between e.s.d.'s in cell parameters are only used when they are defined by crystal symmetry. An approximate (isotropic) treatment of cell e.s.d.'s is used for estimating e.s.d.'s involving 1.s. planes.

Refinement. Refinement of $F^{2}$ against ALL reflections. The weighted $R$-factor $w R$ and goodness of fit $S$ are based on $F^{2}$, conventional $R$-factors $R$ are based on $F$, with $F$ set to zero for negative $F^{2}$. The threshold expression of $F^{2}>\sigma\left(F^{2}\right)$ is used only for calculating $R$-factors(gt) etc. and is not relevant to the choice of reflections for refinement. $R$-factors based on $F^{2}$ are statistically about twice as large as those based on $F$, and $R$ - factors based on ALL data will be even larger.

Fractional atomic coordinates and isotropic or equivalent isotropic displacement parameters $\left(\AA^{2}\right)$

\begin{tabular}{lllll}
\hline & $x$ & $y$ & $z$ & $U_{\text {iso }} * / U_{\text {eq }}$ \\
\hline Zn1 & $0.47946(2)$ & $0.566124(16)$ & $0.26276(2)$ & $0.02202(7)$ \\
V1 & $1.01192(3)$ & $0.52639(2)$ & $0.74230(3)$ & $0.01679(8)$ \\
P1 & $0.81721(5)$ & $0.55866(3)$ & $0.44467(5)$ & $0.01775(10)$ \\
N1 & $0.98913(17)$ & $0.66771(11)$ & $0.63798(15)$ & $0.0188(3)$ \\
O5 & $0.85567(14)$ & $0.49988(10)$ & $0.57024(13)$ & $0.0223(3)$ \\
O7 & $0.66854(14)$ & $0.59666(10)$ & $0.40459(14)$ & $0.0242(3)$ \\
O4 & $1.16206(16)$ & $0.60558(10)$ & $0.87361(13)$ & $0.0252(3)$ \\
C5 & $0.9481(2)$ & $0.65025(13)$ & $0.49415(17)$ & $0.0199(3)$ \\
H5A & 1.0323 & 0.6340 & 0.4747 & $0.024 *$ \\
H5B & 0.9072 & 0.7041 & 0.4446 & $0.024 *$ \\
O6 & $0.83989(15)$ & $0.50552(10)$ & $0.33263(14)$ & $0.0249(3)$ \\
O2 & $0.86146(16)$ & $0.59104(10)$ & $0.79428(16)$ & $0.0275(3)$ \\
C4 & $1.1990(2)$ & $0.68247(13)$ & $0.84317(19)$ & $0.0229(4)$ \\
C1 & $0.8075(2)$ & $0.66657(14)$ & $0.7474(2)$ & $0.0239(4)$ \\
O8 & $1.0159(2)$ & $0.43890(11)$ & $0.83081(18)$ & $0.0348(4)$ \\
C3 & $1.1313(2)$ & $0.71027(15)$ & $0.69835(19)$ & $0.0263(4)$ \\
H3A & 1.1213 & 0.7751 & 0.6922 & $0.032 *$ \\
H3B & 1.1924 & 0.6920 & 0.6509 & $0.032 *$ \\
C2 & $0.8762(2)$ & $0.71885(14)$ & $0.6657(2)$ & $0.0266(4)$ \\
H2A & 0.8027 & 0.7359 & 0.5824 & $0.032 *$
\end{tabular}




$\begin{array}{lllll}\text { H2B } & 0.9176 & 0.7736 & 0.7125 & 0.032^{*} \\ \text { O3 } & 1.28796(19) & 0.73187(12) & 0.92367(16) & 0.0371(4) \\ \text { O1 } & 0.70218(18) & 0.69941(11) & 0.76509(19) & 0.0360(4) \\ \text { O1W } & 0.5041(2) & 0.43314(11) & 0.32805(19) & 0.0392(4) \\ \text { H1W } & 0.440(3) & 0.390(2) & 0.288(3) & 0.059^{*} \\ \text { H2W } & 0.528(4) & 0.419(2) & 0.414(2) & 0.059^{*} \\ \text { O2W } & 0.36824(16) & 0.59655(11) & 0.39610(15) & 0.0266(3) \\ \text { H3W } & 0.348(3) & 0.6535(14) & 0.402(3) & 0.040^{*} \\ \text { H4W } & 0.298(3) & 0.5638(17) & 0.401(3) & 0.040^{*} \\ \text { O3W } & 0.28954(18) & 0.52927(14) & 0.11685(17) & 0.0409(4) \\ \text { H5W } & 0.238(4) & 0.560(2) & 0.045(3) & 0.061^{*} \\ \text { H6W } & 0.234(4) & 0.491(2) & 0.136(3) & 0.061^{*} \\ \text { O4W } & 0.45023(17) & 0.69926(11) & 0.19464(16) & 0.0304(3) \\ \text { H7W } & 0.397(3) & 0.706(2) & 0.113(2) & 0.046^{*} \\ \text { H8W } & 0.531(3) & 0.727(2) & 0.205(3) & 0.046^{*} \\ \text { O5W } & 0.58091(19) & 0.53840(17) & 0.12317(18) & 0.0446(5) \\ \text { H9W } & 0.666(3) & 0.513(2) & 0.170(3) & 0.067^{*} \\ \text { H10W } & 0.598(4) & 0.574(2) & 0.068(3) & 0.067^{*} \\ \text { O6W } & 0.5884(6) & 0.6734(4) & -0.0345(5) & 0.1474(18)\end{array}$

Atomic displacement parameters $\left(\AA^{2}\right)$

\begin{tabular}{lllllll}
\hline & $U^{11}$ & $U^{22}$ & $U^{33}$ & $U^{12}$ & $U^{13}$ & $U^{23}$ \\
\hline Zn1 & $0.01727(12)$ & $0.02490(13)$ & $0.01985(12)$ & $-0.00060(8)$ & $0.00183(8)$ & $0.00210(8)$ \\
V1 & $0.01574(14)$ & $0.01789(15)$ & $0.01586(14)$ & $0.00001(10)$ & $0.00464(11)$ & $0.00076(10)$ \\
P1 & $0.01270(19)$ & $0.0220(2)$ & $0.0165(2)$ & $-0.00024(16)$ & $0.00279(16)$ & $-0.00184(16)$ \\
N1 & $0.0182(7)$ & $0.0201(7)$ & $0.0165(7)$ & $-0.0029(6)$ & $0.0045(5)$ & $-0.0002(5)$ \\
O5 & $0.0185(6)$ & $0.0238(6)$ & $0.0206(6)$ & $-0.0037(5)$ & $0.0023(5)$ & $0.0009(5)$ \\
O7 & $0.0142(6)$ & $0.0304(7)$ & $0.0239(6)$ & $0.0025(5)$ & $0.0018(5)$ & $-0.0048(6)$ \\
O4 & $0.0279(7)$ & $0.0252(7)$ & $0.0171(6)$ & $-0.0049(6)$ & $0.0017(5)$ & $0.0016(5)$ \\
C5 & $0.0195(8)$ & $0.0232(8)$ & $0.0152(7)$ & $-0.0024(7)$ & $0.0041(6)$ & $0.0014(6)$ \\
O6 & $0.0177(6)$ & $0.0331(7)$ & $0.0233(6)$ & $-0.0002(5)$ & $0.0067(5)$ & $-0.0079(6)$ \\
O2 & $0.0287(7)$ & $0.0247(7)$ & $0.0357(8)$ & $0.0029(6)$ & $0.0196(6)$ & $0.0039(6)$ \\
C4 & $0.0210(8)$ & $0.0251(9)$ & $0.0190(8)$ & $-0.0035(7)$ & $0.0026(7)$ & $0.0003(7)$ \\
C1 & $0.0227(9)$ & $0.0225(9)$ & $0.0270(9)$ & $-0.0022(7)$ & $0.0094(7)$ & $-0.0053(7)$ \\
O8 & $0.0410(9)$ & $0.0272(8)$ & $0.0383(9)$ & $0.0017(7)$ & $0.0169(7)$ & $0.0086(7)$ \\
C3 & $0.0248(9)$ & $0.0288(10)$ & $0.0202(8)$ & $-0.0110(8)$ & $0.0021(7)$ & $0.0036(7)$ \\
C2 & $0.0337(10)$ & $0.0189(8)$ & $0.0299(10)$ & $0.0036(8)$ & $0.0148(8)$ & $0.0009(7)$ \\
O3 & $0.0405(9)$ & $0.0334(8)$ & $0.0242(7)$ & $-0.0151(7)$ & $-0.0043(7)$ & $0.0007(6)$ \\
O1 & $0.0305(8)$ & $0.0297(8)$ & $0.0538(10)$ & $0.0047(6)$ & $0.0226(8)$ & $-0.0033(7)$ \\
O1W & $0.0428(10)$ & $0.0270(8)$ & $0.0340(9)$ & $-0.0057(7)$ & $-0.0029(7)$ & $0.0044(7)$ \\
O2W & $0.0235(7)$ & $0.0261(7)$ & $0.0316(7)$ & $-0.0003(6)$ & $0.0117(6)$ & $0.0027(6)$ \\
O3W & $0.0269(8)$ & $0.0578(12)$ & $0.0266(8)$ & $-0.0179(8)$ & $-0.0040(6)$ & $0.0167(8)$ \\
O4W & $0.0274(7)$ & $0.0287(8)$ & $0.0303(8)$ & $-0.0041(6)$ & $0.0046(6)$ & $0.0066(6)$ \\
O5W & $0.0281(8)$ & $0.0761(14)$ & $0.0268(8)$ & $0.0078(9)$ & $0.0064(7)$ & $-0.0058(9)$ \\
O6W & $0.163(4)$ & $0.159(5)$ & $0.143(4)$ & $-0.009(4)$ & $0.083(4)$ & $0.009(3)$ \\
& & & & & & \\
\hline
\end{tabular}


Geometric parameters $\left(\AA,{ }^{\circ}\right)$

\begin{tabular}{|c|c|c|c|}
\hline $\mathrm{Zn1-O}$ & $2.0133(14)$ & $\mathrm{C} 5-\mathrm{H} 5 \mathrm{~B}$ & 0.9700 \\
\hline $\mathrm{Zn} 1-\mathrm{O} 3 \mathrm{~W}$ & $2.0609(16)$ & $\mathrm{O} 6-\mathrm{V} 1^{\mathrm{i}}$ & $1.9890(14)$ \\
\hline $\mathrm{Zn} 1-\mathrm{O} 1 \mathrm{~W}$ & $2.0860(17)$ & $\mathrm{O} 2-\mathrm{C} 1$ & $1.271(3)$ \\
\hline $\mathrm{Zn} 1-\mathrm{O} 4 \mathrm{~W}$ & $2.0974(16)$ & $\mathrm{C} 4-\mathrm{O} 3$ & $1.238(2)$ \\
\hline $\mathrm{Zn} 1-\mathrm{O} 5 \mathrm{~W}$ & $2.1440(18)$ & $\mathrm{C} 4-\mathrm{C} 3$ & $1.524(3)$ \\
\hline $\mathrm{Zn} 1-\mathrm{O} 2 \mathrm{~W}$ & $2.1660(15)$ & $\mathrm{C} 1-\mathrm{O} 1$ & $1.239(3)$ \\
\hline $\mathrm{V} 1-\mathrm{O} 8$ & $1.6086(16)$ & $\mathrm{C} 1-\mathrm{C} 2$ & $1.517(3)$ \\
\hline $\mathrm{V} 1-\mathrm{O}^{\mathrm{i}}$ & $1.9890(14)$ & $\mathrm{C} 3-\mathrm{H} 3 \mathrm{~A}$ & 0.9700 \\
\hline $\mathrm{V} 1-\mathrm{O} 5$ & $1.9932(14)$ & $\mathrm{C} 3-\mathrm{H} 3 \mathrm{~B}$ & 0.9700 \\
\hline $\mathrm{V} 1-\mathrm{O} 2$ & $2.0312(15)$ & $\mathrm{C} 2-\mathrm{H} 2 \mathrm{~A}$ & 0.9700 \\
\hline $\mathrm{V} 1-\mathrm{O} 4$ & $2.0321(14)$ & $\mathrm{C} 2-\mathrm{H} 2 \mathrm{~B}$ & 0.9700 \\
\hline $\mathrm{V} 1-\mathrm{N} 1$ & $2.3590(16)$ & $\mathrm{O} 1 \mathrm{~W}-\mathrm{H} 1 \mathrm{~W}$ & $0.90(2)$ \\
\hline $\mathrm{P} 1-\mathrm{O} 7$ & $1.5030(14)$ & $\mathrm{O} 1 \mathrm{~W}-\mathrm{H} 2 \mathrm{~W}$ & $0.90(2)$ \\
\hline $\mathrm{P} 1-\mathrm{O} 6$ & $1.5324(15)$ & $\mathrm{O} 2 \mathrm{~W}-\mathrm{H} 3 \mathrm{~W}$ & $0.88(2)$ \\
\hline $\mathrm{P} 1-\mathrm{O} 5$ & $1.5443(14)$ & $\mathrm{O} 2 \mathrm{~W}-\mathrm{H} 4 \mathrm{~W}$ & $0.87(2)$ \\
\hline $\mathrm{P} 1-\mathrm{C} 5$ & $1.8323(19)$ & $\mathrm{O} 3 \mathrm{~W}-\mathrm{H} 5 \mathrm{~W}$ & $0.89(2)$ \\
\hline $\mathrm{N} 1-\mathrm{C} 3$ & $1.478(2)$ & $\mathrm{O} 3 \mathrm{~W}-\mathrm{H} 6 \mathrm{~W}$ & $0.88(2)$ \\
\hline $\mathrm{N} 1-\mathrm{C} 2$ & $1.481(3)$ & $\mathrm{O} 4 \mathrm{~W}-\mathrm{H} 7 \mathrm{~W}$ & $0.86(2)$ \\
\hline $\mathrm{N} 1-\mathrm{C} 5$ & $1.484(2)$ & $\mathrm{O} 4 \mathrm{~W}-\mathrm{H} 8 \mathrm{~W}$ & $0.88(2)$ \\
\hline $\mathrm{O} 4-\mathrm{C} 4$ & $1.282(2)$ & O5W-H9W & $0.90(2)$ \\
\hline $\mathrm{C} 5-\mathrm{H} 5 \mathrm{~A}$ & 0.9700 & $\mathrm{O} 5 \mathrm{~W}-\mathrm{H} 10 \mathrm{~W}$ & $0.86(2)$ \\
\hline $\mathrm{O} 7-\mathrm{Zn} 1-\mathrm{O} 3 \mathrm{~W}$ & $177.43(8)$ & $\mathrm{P} 1-\mathrm{O} 7-\mathrm{Zn} 1$ & $134.17(9)$ \\
\hline $\mathrm{O} 7-\mathrm{Zn} 1-\mathrm{O} 1 \mathrm{~W}$ & $89.53(7)$ & $\mathrm{C} 4-\mathrm{O} 4-\mathrm{V} 1$ & $123.17(12)$ \\
\hline $\mathrm{O} 3 \mathrm{~W}-\mathrm{Zn} 1-\mathrm{O} 1 \mathrm{~W}$ & $88.34(7)$ & $\mathrm{N} 1-\mathrm{C} 5-\mathrm{P} 1$ & $109.58(12)$ \\
\hline $\mathrm{O} 7-\mathrm{Zn} 1-\mathrm{O} 4 \mathrm{~W}$ & $91.64(6)$ & $\mathrm{N} 1-\mathrm{C} 5-\mathrm{H} 5 \mathrm{~A}$ & 109.8 \\
\hline $\mathrm{O} 3 \mathrm{~W}-\mathrm{Zn} 1-\mathrm{O} 4 \mathrm{~W}$ & $90.49(7)$ & $\mathrm{P} 1-\mathrm{C} 5-\mathrm{H} 5 \mathrm{~A}$ & 109.8 \\
\hline $\mathrm{O} 1 \mathrm{~W}-\mathrm{Zn} 1-\mathrm{O} 4 \mathrm{~W}$ & $178.81(7)$ & $\mathrm{N} 1-\mathrm{C} 5-\mathrm{H} 5 \mathrm{~B}$ & 109.8 \\
\hline $\mathrm{O} 7-\mathrm{Zn} 1-\mathrm{O} 5 \mathrm{~W}$ & $91.53(6)$ & $\mathrm{P} 1-\mathrm{C} 5-\mathrm{H} 5 \mathrm{~B}$ & 109.8 \\
\hline $\mathrm{O} 3 \mathrm{~W}-\mathrm{Zn} 1-\mathrm{O} 5 \mathrm{~W}$ & $87.09(8)$ & $\mathrm{H} 5 \mathrm{~A}-\mathrm{C} 5-\mathrm{H} 5 \mathrm{~B}$ & 108.2 \\
\hline $\mathrm{O} 1 \mathrm{~W}-\mathrm{Zn} 1-\mathrm{O} 5 \mathrm{~W}$ & $91.61(9)$ & $\mathrm{P} 1-\mathrm{O} 6-\mathrm{V} 1^{\mathrm{i}}$ & $142.36(9)$ \\
\hline $\mathrm{O} 4 \mathrm{~W}-\mathrm{Zn} 1-\mathrm{O} 5 \mathrm{~W}$ & $88.58(8)$ & $\mathrm{C} 1-\mathrm{O} 2-\mathrm{V} 1$ & $123.99(13)$ \\
\hline $\mathrm{O} 7-\mathrm{Zn} 1-\mathrm{O} 2 \mathrm{~W}$ & $90.73(6)$ & $\mathrm{O} 3-\mathrm{C} 4-\mathrm{O} 4$ & $123.37(18)$ \\
\hline $\mathrm{O} 3 \mathrm{~W}-\mathrm{Zn} 1-\mathrm{O} 2 \mathrm{~W}$ & $90.71(7)$ & $\mathrm{O} 3-\mathrm{C} 4-\mathrm{C} 3$ & $120.23(18)$ \\
\hline $\mathrm{O} 1 \mathrm{~W}-\mathrm{Zn} 1-\mathrm{O} 2 \mathrm{~W}$ & $89.93(7)$ & $\mathrm{O} 4-\mathrm{C} 4-\mathrm{C} 3$ & $116.37(16)$ \\
\hline $\mathrm{O} 4 \mathrm{~W}-\mathrm{Zn} 1-\mathrm{O} 2 \mathrm{~W}$ & $89.83(6)$ & $\mathrm{O} 1-\mathrm{C} 1-\mathrm{O} 2$ & $123.4(2)$ \\
\hline $\mathrm{O} 5 \mathrm{~W}-\mathrm{Zn} 1-\mathrm{O} 2 \mathrm{~W}$ & $177.27(7)$ & $\mathrm{O} 1-\mathrm{C} 1-\mathrm{C} 2$ & $118.61(19)$ \\
\hline $\mathrm{O} 8-\mathrm{V} 1-\mathrm{O}^{\mathrm{i}}$ & $100.84(8)$ & $\mathrm{O} 2-\mathrm{C} 1-\mathrm{C} 2$ & $118.02(17)$ \\
\hline $\mathrm{O} 8-\mathrm{V} 1-\mathrm{O} 5$ & $103.84(8)$ & $\mathrm{N} 1-\mathrm{C} 3-\mathrm{C} 4$ & $109.82(15)$ \\
\hline $\mathrm{O} 6 \mathrm{i}-\mathrm{V} 1-\mathrm{O} 5$ & $91.21(6)$ & $\mathrm{N} 1-\mathrm{C} 3-\mathrm{H} 3 \mathrm{~A}$ & 109.7 \\
\hline $\mathrm{O} 8-\mathrm{V} 1-\mathrm{O} 2$ & $94.57(8)$ & $\mathrm{C} 4-\mathrm{C} 3-\mathrm{H} 3 \mathrm{~A}$ & 109.7 \\
\hline $\mathrm{O} 6^{\mathrm{i}}-\mathrm{V} 1-\mathrm{O} 2$ & $164.50(7)$ & $\mathrm{N} 1-\mathrm{C} 3-\mathrm{H} 3 \mathrm{~B}$ & 109.7 \\
\hline $\mathrm{O} 5-\mathrm{V} 1-\mathrm{O} 2$ & $86.67(6)$ & $\mathrm{C} 4-\mathrm{C} 3-\mathrm{H} 3 \mathrm{~B}$ & 109.7 \\
\hline $\mathrm{O} 8-\mathrm{V} 1-\mathrm{O} 4$ & $101.49(8)$ & $\mathrm{H} 3 \mathrm{~A}-\mathrm{C} 3-\mathrm{H} 3 \mathrm{~B}$ & 108.2 \\
\hline $\mathrm{O} 6-\mathrm{i}-\mathrm{V} 1-\mathrm{O} 4$ & $87.20(6)$ & $\mathrm{N} 1-\mathrm{C} 2-\mathrm{C} 1$ & $113.27(16)$ \\
\hline $\mathrm{O} 5-\mathrm{V} 1-\mathrm{O} 4$ & $154.45(6)$ & $\mathrm{N} 1-\mathrm{C} 2-\mathrm{H} 2 \mathrm{~A}$ & 108.9 \\
\hline
\end{tabular}




\begin{tabular}{|c|c|c|c|}
\hline $\mathrm{O} 2-\mathrm{V} 1-\mathrm{O} 4$ & $88.12(6)$ & $\mathrm{C} 1-\mathrm{C} 2-\mathrm{H} 2 \mathrm{~A}$ & 108.9 \\
\hline $\mathrm{O} 8-\mathrm{V} 1-\mathrm{N} 1$ & $169.79(8)$ & $\mathrm{N} 1-\mathrm{C} 2-\mathrm{H} 2 \mathrm{~B}$ & 108.9 \\
\hline $\mathrm{O} 6{ }^{\mathrm{i}}-\mathrm{V} 1-\mathrm{N} 1$ & $88.57(6)$ & $\mathrm{C} 1-\mathrm{C} 2-\mathrm{H} 2 \mathrm{~B}$ & 108.9 \\
\hline $\mathrm{O} 5-\mathrm{V} 1-\mathrm{N} 1$ & $79.69(6)$ & $\mathrm{H} 2 \mathrm{~A}-\mathrm{C} 2-\mathrm{H} 2 \mathrm{~B}$ & 107.7 \\
\hline $\mathrm{O} 2-\mathrm{V} 1-\mathrm{N} 1$ & $75.95(6)$ & $\mathrm{Zn} 1-\mathrm{O} 1 \mathrm{~W}-\mathrm{H} 1 \mathrm{~W}$ & $122(2)$ \\
\hline $\mathrm{O} 4-\mathrm{V} 1-\mathrm{N} 1$ & $74.78(6)$ & $\mathrm{Zn} 1-\mathrm{O} 1 \mathrm{~W}-\mathrm{H} 2 \mathrm{~W}$ & $121(2)$ \\
\hline $\mathrm{O} 7-\mathrm{P} 1-\mathrm{O} 6$ & $112.33(8)$ & $\mathrm{H} 1 \mathrm{~W}-\mathrm{O} 1 \mathrm{~W}-\mathrm{H} 2 \mathrm{~W}$ & $103(3)$ \\
\hline $\mathrm{O} 7-\mathrm{P} 1-\mathrm{O} 5$ & $111.96(8)$ & $\mathrm{Zn} 1-\mathrm{O} 2 \mathrm{~W}-\mathrm{H} 3 \mathrm{~W}$ & $115.9(19)$ \\
\hline $\mathrm{O} 6-\mathrm{P} 1-\mathrm{O} 5$ & $110.11(9)$ & $\mathrm{Zn} 1-\mathrm{O} 2 \mathrm{~W}-\mathrm{H} 4 \mathrm{~W}$ & $123(2)$ \\
\hline $\mathrm{O} 7-\mathrm{P} 1-\mathrm{C} 5$ & $109.55(9)$ & $\mathrm{H} 3 \mathrm{~W}-\mathrm{O} 2 \mathrm{~W}-\mathrm{H} 4 \mathrm{~W}$ & $109(2)$ \\
\hline $\mathrm{O} 6-\mathrm{P} 1-\mathrm{C} 5$ & $108.69(8)$ & $\mathrm{Zn} 1-\mathrm{O} 3 \mathrm{~W}-\mathrm{H} 5 \mathrm{~W}$ & $128(2)$ \\
\hline $\mathrm{O} 5-\mathrm{P} 1-\mathrm{C} 5$ & $103.82(8)$ & $\mathrm{Zn} 1-\mathrm{O} 3 \mathrm{~W}-\mathrm{H} 6 \mathrm{~W}$ & $119(2)$ \\
\hline $\mathrm{C} 3-\mathrm{N} 1-\mathrm{C} 2$ & $111.98(16)$ & $\mathrm{H} 5 \mathrm{~W}-\mathrm{O} 3 \mathrm{~W}-\mathrm{H} 6 \mathrm{~W}$ & $109(3)$ \\
\hline $\mathrm{C} 3-\mathrm{N} 1-\mathrm{C} 5$ & $113.40(15)$ & $\mathrm{Zn} 1-\mathrm{O} 4 \mathrm{~W}-\mathrm{H} 7 \mathrm{~W}$ & $115(2)$ \\
\hline $\mathrm{C} 2-\mathrm{N} 1-\mathrm{C} 5$ & $111.14(15)$ & $\mathrm{Zn} 1-\mathrm{O} 4 \mathrm{~W}-\mathrm{H} 8 \mathrm{~W}$ & $113(2)$ \\
\hline $\mathrm{C} 3-\mathrm{N} 1-\mathrm{V} 1$ & $105.00(11)$ & $\mathrm{H} 7 \mathrm{~W}-\mathrm{O} 4 \mathrm{~W}-\mathrm{H} 8 \mathrm{~W}$ & $106(3)$ \\
\hline $\mathrm{C} 2-\mathrm{N} 1-\mathrm{V} 1$ & $108.06(11)$ & $\mathrm{Zn} 1-\mathrm{O} 5 \mathrm{~W}-\mathrm{H} 9 \mathrm{~W}$ & $106(2)$ \\
\hline $\mathrm{C} 5-\mathrm{N} 1-\mathrm{V} 1$ & $106.80(11)$ & $\mathrm{Zn} 1-\mathrm{O} 5 \mathrm{~W}-\mathrm{H} 10 \mathrm{~W}$ & $130(3)$ \\
\hline $\mathrm{P} 1-\mathrm{O} 5-\mathrm{V} 1$ & $124.99(8)$ & $\mathrm{H} 9 \mathrm{~W}-\mathrm{O} 5 \mathrm{~W}-\mathrm{H} 10 \mathrm{~W}$ & $105(3)$ \\
\hline $\mathrm{O} 8-\mathrm{V} 1-\mathrm{N} 1-\mathrm{C} 3$ & $95.2(5)$ & $\mathrm{O} 5-\mathrm{V} 1-\mathrm{O} 4-\mathrm{C} 4$ & $-10.3(3)$ \\
\hline $\mathrm{O} 6 \mathrm{i}-\mathrm{V} 1-\mathrm{N} 1-\mathrm{C} 3$ & $-62.07(12)$ & $\mathrm{O} 2-\mathrm{V} 1-\mathrm{O} 4-\mathrm{C} 4$ & $-88.53(16)$ \\
\hline $\mathrm{O} 5-\mathrm{V} 1-\mathrm{N} 1-\mathrm{C} 3$ & $-153.56(13)$ & $\mathrm{N} 1-\mathrm{V} 1-\mathrm{O} 4-\mathrm{C} 4$ & $-12.59(15)$ \\
\hline $\mathrm{O} 2-\mathrm{V} 1-\mathrm{N} 1-\mathrm{C} 3$ & $117.32(13)$ & $\mathrm{C} 3-\mathrm{N} 1-\mathrm{C} 5-\mathrm{P} 1$ & $155.80(14)$ \\
\hline $\mathrm{O} 4-\mathrm{V} 1-\mathrm{N} 1-\mathrm{C} 3$ & $25.42(12)$ & $\mathrm{C} 2-\mathrm{N} 1-\mathrm{C} 5-\mathrm{P} 1$ & $-77.01(17)$ \\
\hline $\mathrm{O} 8-\mathrm{V} 1-\mathrm{N} 1-\mathrm{C} 2$ & $-24.5(5)$ & $\mathrm{V} 1-\mathrm{N} 1-\mathrm{C} 5-\mathrm{P} 1$ & $40.64(13)$ \\
\hline $\mathrm{O} 6-\mathrm{V} 1-\mathrm{N} 1-\mathrm{C} 2$ & $178.27(13)$ & $\mathrm{O} 7-\mathrm{P} 1-\mathrm{C} 5-\mathrm{N} 1$ & $89.70(14)$ \\
\hline $\mathrm{O} 5-\mathrm{V} 1-\mathrm{N} 1-\mathrm{C} 2$ & $86.78(13)$ & $\mathrm{O} 6-\mathrm{P} 1-\mathrm{C} 5-\mathrm{N} 1$ & $-147.23(12)$ \\
\hline $\mathrm{O} 2-\mathrm{V} 1-\mathrm{N} 1-\mathrm{C} 2$ & $-2.35(12)$ & $\mathrm{O} 5-\mathrm{P} 1-\mathrm{C} 5-\mathrm{N} 1$ & $-30.04(15)$ \\
\hline $\mathrm{O} 4-\mathrm{V} 1-\mathrm{N} 1-\mathrm{C} 2$ & $-94.24(13)$ & $\mathrm{O} 7-\mathrm{P} 1-\mathrm{O} 6-\mathrm{V} 1^{\mathrm{i}}$ & $147.90(15)$ \\
\hline $\mathrm{O} 8-\mathrm{V} 1-\mathrm{N} 1-\mathrm{C} 5$ & $-144.1(4)$ & $\mathrm{O} 5-\mathrm{P} 1-\mathrm{O} 6-\mathrm{V} 1^{\mathrm{i}}$ & $-86.60(17)$ \\
\hline $\mathrm{O} 6-\mathrm{V} 1-\mathrm{N} 1-\mathrm{C} 5$ & $58.62(11)$ & $\mathrm{C} 5-\mathrm{P} 1-\mathrm{O} 6-\mathrm{V} 1^{\mathrm{i}}$ & $26.51(19)$ \\
\hline $\mathrm{O} 5-\mathrm{V} 1-\mathrm{N} 1-\mathrm{C} 5$ & $-32.88(11)$ & $\mathrm{O} 8-\mathrm{V} 1-\mathrm{O} 2-\mathrm{C} 1$ & $-176.55(17)$ \\
\hline $\mathrm{O} 2-\mathrm{V} 1-\mathrm{N} 1-\mathrm{C} 5$ & $-122.00(12)$ & $\mathrm{O} 6-\mathrm{V} 1-\mathrm{O} 2-\mathrm{C} 1$ & $9.6(4)$ \\
\hline $\mathrm{O} 4-\mathrm{V} 1-\mathrm{N} 1-\mathrm{C} 5$ & $146.11(12)$ & $\mathrm{O} 5-\mathrm{V} 1-\mathrm{O} 2-\mathrm{C} 1$ & $-72.91(17)$ \\
\hline $\mathrm{O} 7-\mathrm{P} 1-\mathrm{O} 5-\mathrm{V} 1$ & $-116.85(10)$ & $\mathrm{O} 4-\mathrm{V} 1-\mathrm{O} 2-\mathrm{C} 1$ & $82.07(17)$ \\
\hline $\mathrm{O} 6-\mathrm{P} 1-\mathrm{O} 5-\mathrm{V} 1$ & $117.44(10)$ & $\mathrm{N} 1-\mathrm{V} 1-\mathrm{O} 2-\mathrm{C} 1$ & $7.29(16)$ \\
\hline $\mathrm{C} 5-\mathrm{P} 1-\mathrm{O} 5-\mathrm{V} 1$ & $1.24(12)$ & $\mathrm{V} 1-\mathrm{O} 4-\mathrm{C} 4-\mathrm{O} 3$ & $178.20(17)$ \\
\hline $\mathrm{O} 8-\mathrm{V} 1-\mathrm{O} 5-\mathrm{P} 1$ & $-173.68(11)$ & $\mathrm{V} 1-\mathrm{O} 4-\mathrm{C} 4-\mathrm{C} 3$ & $-4.0(3)$ \\
\hline $\mathrm{O} 6-\mathrm{V} 1-\mathrm{O} 5-\mathrm{P} 1$ & $-72.20(11)$ & $\mathrm{V} 1-\mathrm{O} 2-\mathrm{C} 1-\mathrm{O} 1$ & $169.44(16)$ \\
\hline $\mathrm{O} 2-\mathrm{V} 1-\mathrm{O} 5-\mathrm{P} 1$ & $92.43(11)$ & $\mathrm{V} 1-\mathrm{O} 2-\mathrm{C} 1-\mathrm{C} 2$ & $-10.6(3)$ \\
\hline $\mathrm{O} 4-\mathrm{V} 1-\mathrm{O} 5-\mathrm{P} 1$ & $13.8(2)$ & $\mathrm{C} 2-\mathrm{N} 1-\mathrm{C} 3-\mathrm{C} 4$ & $83.0(2)$ \\
\hline $\mathrm{N} 1-\mathrm{V} 1-\mathrm{O} 5-\mathrm{P} 1$ & $16.12(10)$ & $\mathrm{C} 5-\mathrm{N} 1-\mathrm{C} 3-\mathrm{C} 4$ & $-150.29(17)$ \\
\hline $\mathrm{O} 6-\mathrm{P} 1-\mathrm{O} 7-\mathrm{Zn} 1$ & $21.40(16)$ & $\mathrm{V} 1-\mathrm{N} 1-\mathrm{C} 3-\mathrm{C} 4$ & $-34.07(19)$ \\
\hline $\mathrm{O} 5-\mathrm{P} 1-\mathrm{O} 7-\mathrm{Zn} 1$ & $-103.09(13)$ & $\mathrm{O} 3-\mathrm{C} 4-\mathrm{C} 3-\mathrm{N} 1$ & $-153.7(2)$ \\
\hline $\mathrm{C} 5-\mathrm{P} 1-\mathrm{O} 7-\mathrm{Zn} 1$ & $142.29(12)$ & $\mathrm{O} 4-\mathrm{C} 4-\mathrm{C} 3-\mathrm{N} 1$ & $28.5(3)$ \\
\hline $\mathrm{O} 1 \mathrm{~W}-\mathrm{Zn} 1-\mathrm{O} 7-\mathrm{P} 1$ & $52.88(14)$ & $\mathrm{C} 3-\mathrm{N} 1-\mathrm{C} 2-\mathrm{C} 1$ & $-116.61(19)$ \\
\hline $\mathrm{O} 4 \mathrm{~W}-\mathrm{Zn} 1-\mathrm{O} 7-\mathrm{P} 1$ & $-127.34(14)$ & $\mathrm{C} 5-\mathrm{N} 1-\mathrm{C} 2-\mathrm{C} 1$ & $115.43(18)$ \\
\hline
\end{tabular}




$\begin{array}{llll}\mathrm{O} 5 \mathrm{~W}-\mathrm{Zn} 1-\mathrm{O} 7-\mathrm{P} 1 & -38.72(15) & \mathrm{V} 1-\mathrm{N} 1-\mathrm{C} 2-\mathrm{C} 1 & -1.4(2) \\ \text { O2W-Zn1-O7-P1 } & 142.81(13) & \mathrm{O} 1-\mathrm{C} 1-\mathrm{C} 2-\mathrm{N} 1 & -172.84(19) \\ \mathrm{O} 8-\mathrm{V} 1-\mathrm{O} 4-\mathrm{C} 4 & 177.18(16) & \mathrm{O} 2-\mathrm{C} 1-\mathrm{C} 2-\mathrm{N} 1 & 7.2(3) \\ \text { O66-V1-O4-C4 } & 76.69(16) & & \end{array}$

Symmetry code: (i) $-x+2,-y+1,-z+1$.

Hydrogen-bond geometry $\left(\AA,{ }^{\circ}\right)$

\begin{tabular}{lllll}
\hline$D-\mathrm{H} \cdots A$ & $D-\mathrm{H}$ & $\mathrm{H} \cdots A$ & $D \cdots A$ & $D-\mathrm{H} \cdots A$ \\
\hline $\mathrm{O} 1 W-\mathrm{H} 1 W^{\cdots} \cdots \mathrm{O} 1^{\mathrm{ii}}$ & $0.90(2)$ & $1.88(2)$ & $2.770(2)$ & $169(3)$ \\
$\mathrm{O} 1 W-\mathrm{H} 2 W \cdots \mathrm{O} 2 W^{\mathrm{ii}}$ & $0.90(2)$ & $1.95(2)$ & $2.828(2)$ & $164(3)$ \\
$\mathrm{O} 2 W-\mathrm{H} 3 W \cdots \mathrm{O} 3^{\text {iii }}$ & $0.88(2)$ & $1.85(2)$ & $2.725(2)$ & $172(3)$ \\
$\mathrm{O} 2 W-\mathrm{H} 4 W \cdots \mathrm{O} 5^{\mathrm{ii}}$ & $0.87(2)$ & $1.93(2)$ & $2.795(2)$ & $173(3)$ \\
$\mathrm{O} 3 W-\mathrm{H} 6 W \cdots \mathrm{O} 2^{\mathrm{ii}}$ & $0.88(2)$ & $1.87(2)$ & $2.733(2)$ & $171(3)$ \\
$\mathrm{O} 3 W-\mathrm{H} 5 W \cdots \mathrm{O} 4^{\text {iv }}$ & $0.89(2)$ & $1.86(2)$ & $2.726(2)$ & $164(4)$ \\
$\mathrm{O} 4 W-\mathrm{H} 7 W \cdots \mathrm{O} 3^{\text {iv }}$ & $0.86(2)$ & $1.98(2)$ & $2.837(2)$ & $174(3)$ \\
$\mathrm{O} 4 W-\mathrm{H} 8 W \cdots \mathrm{O} 1^{v}$ & $0.88(2)$ & $1.94(2)$ & $2.799(2)$ & $167(3)$ \\
$\mathrm{O} 5 W-\mathrm{H} 9 W \cdots \mathrm{O} 6$ & $0.90(2)$ & $1.98(3)$ & $2.805(2)$ & $150(4)$ \\
$\mathrm{O} 5 W-\mathrm{H} 10 W \cdots \mathrm{O} 6 W$ & $0.86(2)$ & $1.84(3)$ & $2.656(6)$ & $159(4)$ \\
\hline
\end{tabular}

Symmetry codes: (ii) $-x+1,-y+1,-z+1$; (iii) $x-1,-y+3 / 2, z-1 / 2$; (iv) $x-1, y, z-1$; (v) $x,-y+3 / 2, z-1 / 2$. 